\title{
NOMINATION SUBMISSIONS
}

The Council of the American Meteorological Society invites members of the AMS to submit nominations for the Society Awards, Lecturers, Named Symposia, Fellows, Honorary members, and nominees for elective Officers and Councilors of the Society.

Information regarding awards, including award descriptions, listings of previous recipients, and the process for submitting nominations are on the AMS Web site www.ametsoc.org/awards.

Note: Deadlines differ and some nominations must be submitted on a specific form vs. electronic submission which is available on the AMS Web site or by request from Headquarters.

\section{AWARDS COMMITTEES}

Each committee or commission listed below has the responsibility to select and submit to the Council the names of individuals nominated for the Society's awards listed. The name(s) of individual(s) nominated, a two-page $\mathrm{cv}$, a bibliography of no more than three pages, and three supporting letters should be electronically submitted before 1 May 2008 for the awards that follow, unless stated otherwise. The nominees for awards remain on the committee's active list for three years.

\section{ATMOSPHERIC RESEARCH AWARDS COMMITTEE}

The Carl-Gustaf Rossby Research Medal

The Jule G. Charney Award

The Verner E. Suomi Award*

The Remote Sensing Prize (biennial)

The Clarence Leroy Meisinger Award

The Henry G. Houghton Award

\section{OCEANOGRAPHIC RESEARCH AWARDS COMMITTEE}

The Sverdrup Gold Medal

The Henry Stommel Research Award

The Verner E. Suomi Award*

The Nicholas P. Fofonoff Award

\section{AWARDS OVERSIGHT COMMITTEE}

The Charles Franklin Brooks Award for Outstanding Services to the Society

The Cleveland Abbe Award for Distinguished Service to the Atmospheric Sciences by an Individual

The Kenneth C. Spengler Award

The Award for Outstanding Services to Meteorology by a Corporation

Special Awards
* Recommended by the Atmospheric Research Awards Committee in even-numbered years and by the Oceanographic Research Awards Committee in odd-numbered years.

\section{EDUCATION AND HUMAN RESOURCES COMMISSION}

The Louis J. Battan Author's Award (Adult and K-12)

The Charles E. Anderson Award

The Teaching Excellence Award

Distinguished Science Journalism in the Atmospheric and Related Sciences

\section{PROFESSIONAL AFFAIRS COMMISSION}

Outstanding Contribution to the Advance of Applied Meteorology Award for Broadcast Meteorology

Award for Excellence in Science Reporting by a Broadcast Meteorologist

\section{SCIENTIFIC AND TECHNOLOGICAL ACTIVITIES COMMISSION}

The Charles L. Mitchell Award

The Award for Exceptional Specific Prediction

The Francis W. Reichelderfer Award

The Helmut E. Landsberg Award

The Award for Outstanding Achievement in Biometeorology

- LeCTURERS (Deadline: 1 October 2008)

Robert E. Horton Lecturer in Hydrology

Bernhard Haurwitz Memorial Lecturer

Walter Orr Roberts Lecturer

- STUDENT PAPERS

Robert Leviton

Banner I. Miller

Max A. Eaton Prize

Spiros G. Geotis Prize

Peter V. Hobbs Prize 


\section{AWARDS COMMITTEES}

\section{- NAMED SYMPOSIA}

Section E, of the Policy, Guidelines, and Procedures for Awards and Lectureships provides the Policy on Named Conferences/Symposia and Special Issues of AMS Journals (full policy description available at $w w w$. ametsoc.org/awards):

\begin{abstract}
Recognition of scientists in the fields served by the AMS, living or deceased, in the form of a named conference or symposium or a named special issue of one of the Society's journals is an honor reserved for only the most outstanding of our colleagues. It should be awarded only to those individuals who are completing a career, or who have recently died having completed a career, of significant achievements in their field and whose contributions would make them worthy of consideration for Honorary Member of the AMS...
\end{abstract}

\section{LOCAL CHAPTER AFFAIRS COMMITTEE}

Local Chapter of the Year Award

(nomination form available online at www.ametsoc. org/amschaps/awardsappl)

\section{FELLOWS COMMITTEE}

The Committee's function is to submit to the Council the names of individuals for election to Fellow.

Article III, Section 6, of the AMS Constitution provides that those eligible for election to Fellow shall have made outstanding contributions to the atmospheric or related oceanic or hydrologic sciences or their applications during a substantial period of years. The nominees for Fellow must be a member of the Society and remain on the committee's active list for three years.

A nomination letter and three supporting letters should be electronically submitted before 1 May 2008. A list of Fellows and the process for submitting nominations are on the AMS Web site (www.ametsoc. org/awards).

\section{NOMINATING COMMITTEE}

The Committee's function is to submit to the Council the names of individuals for 1) the office of President-Elect for a term of one-year starting at the close of the 90th Annual Meeting (January 2010) and 2) four positions on the Council for a term of three-years starting at the close of the Annual Meeting. Nominations must be submitted prior to 1 April 2009 to the Nominating Committee.

\section{HONORARY MEMBERS}

Article III, Section 5, of the AMS Constitution provides that Honorary Members shall be persons of acknowledged preeminence in the atmospheric or related oceanic or hydrologic sciences, either through their own contributions to the sciences or their application or through furtherance of the advance of those sciences in some other way. They shall be exempt from all dues and assessments. The nominees for Honorary member remain on an active list for three years.

Deadline: 1 June 2008; a form and list of Honorary Members is available at www.ametsoc.org/awards. 